\title{
Supporting farmers' management of change towards agroecological practices by focusing on their work: a contribution of ergonomics
}

\author{
Marie Chizallet ${ }^{1,2, *}$, Flore Barcellini ${ }^{1}$ and Lorène Prost ${ }^{2}$ \\ 1 CNAM-CRTD, 41 rue de Gay Lussac, 75005 Paris, France \\ 2 INRA, UMR 1326 LISIS, 77454 Marne-la-Vallée, France
}

\begin{abstract}
The public authorities and some agricultural actors wish to develop agroecology to meet the rise of new challenges (impacts of agricultural practices on natural resources in particular). New agricultural work systems are therefore being designed, and are raising questions about the inclusion of farmers' work in the agroecological transition. Our research-action endeavours to support the development of farmers' change management. To do so, we implement a reflective tool: the "chronicle of change", which appears to be an interesting way to initiate an "enabling intervention in change management" with farmers, and to better understand their work system.
\end{abstract}

Keywords: enabling intervention / design activity / reflective activity / change management / project management

\begin{abstract}
Résumé - Soutenir l'évolution des agriculteurs vers des pratiques agroécologiques en mettant l'accent sur le travail : contribution de l'ergonomie. Les pouvoirs publics et certains acteurs agricoles souhaitent développer l'agroécologie pour faire face à l'émergence de nouveaux défis (impacts des pratiques agricoles sur les ressources naturelles en particulier). De nouveaux systèmes de travail agricole sont donc conçus et posent des questions sur la prise en compte du travail des agriculteurs dans la transition agroécologique. Notre recherche-action s'efforce d'accompagner les agriculteurs dans leur conduite du changement. Pour ce faire, nous mettons en œuvre un outil réflexif: la «chronique du changement», qui semble être un moyen intéressant pour initier une «intervention capacitante en conduite de changement» avec les agriculteurs et mieux comprendre leur système de travail.
\end{abstract}

Mots clés : intervention capacitante / activité de conception / activité réflexive / conduite du changement / conduite de projet

\section{Introduction}

The second half of the twentieth century saw French agriculture significantly increase its productivity per hectare and per worker. However, several limits and negative effects of this model, particularly on the environment and on farmers' health, are now well identified (Meynard et al., 2012). National public policy makers and various stakeholders from research and development organizations are therefore calling for the development of agroecology. A transition towards agroecology involves profound changes in farmers' work and implies a "redesign" of agricultural practices, as proposed by Hill and MacRae (1996). Farmers have to design a new agricultural work system based on agroecological practices, taking into

\footnotetext{
*Auteur correspondant: marie.chizallet@cnam.fr
}

account the changing characteristics of their work. These include: the nature and diversity of constraints faced by farmers; the "evolving and uncertain" nature of agricultural work situations; the influence of the network of actors "revolving" around farms; and the particularities of this context of agroecological transition (Williams, 2011; Duru et al., 2014; Prost et al., 2017). In this sense, it seems necessary to develop farmers' design activity to help them design new agricultural work systems based on agroecological practices. Some studies have already focused on the process of change on farms. For instance, Chantre (2011) examines the learning process of farmers in their shift towards the reduction of inputs in field crops, and Coquil (2014) investigates the motivations, triggers and resources of change throughout the process. In this article, our objective is to contribute to the understanding of farmers' change process, as a basis of more meaningful support that could be offered to them in the design of their work system. 


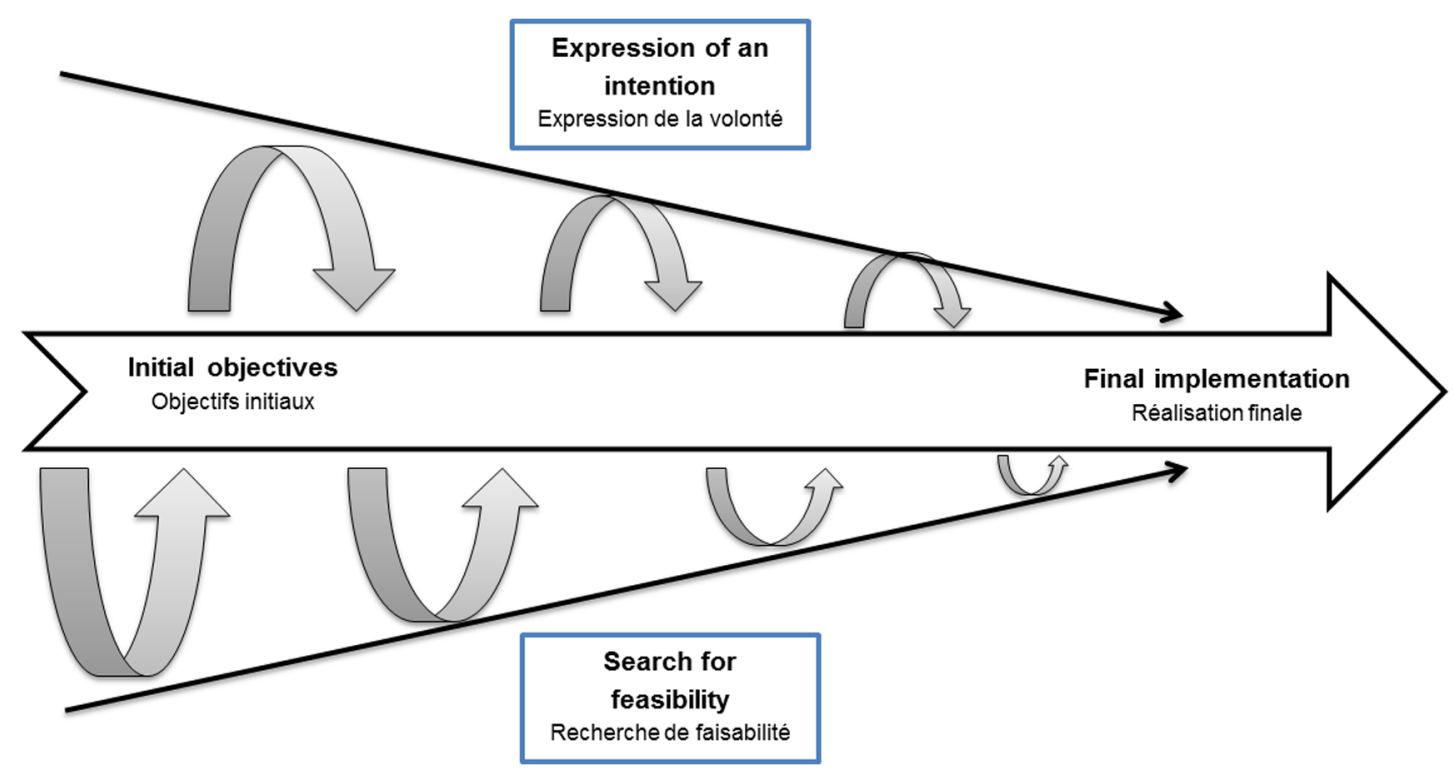

Fig. 1. Diagram of conduct of work system design projects, from Martin (2004) \& Béguin and Pueyo (2011).

Fig. 1. Schéma de conduite de projets de conception de système de travail, à partir de Martin (2004) \& Béguin et Pueyo (2011).

This research-action is situated in the field of constructive ergonomics (Falzon, 2014) and Activity-Centered Ergonomics (ACE) (e.g. Daniellou and Rabardel, 2005) which aims at supporting workers' development through their work. These approaches are interested in investigating work and accompanying the transformations of work by developing a systemic approach and analysis focused on what is called "activity". The concept of activity in ACE can be defined as follows: "activity is not simply the execution of the prescribed tasks, it involves dealing with unforeseen variability, mobilizing individual and collective resources, being involved in contradictions and value debates, and social tensions" (Daniellou, 2007: 82). This type of systemic approach affords a global vision of the farmers' work system while considering its internal dynamics as well (Hollnagel, 2009). Carayon and Smith (2000) include five elements in the work system: individuals, tasks, tools and technologies, physical environment, and organization. Constructive Ergonomics (Falzon, 2014) allows us to anchor change management in the developmental dimension. Our intervention approach is therefore part of the project of conceptualizing what can be an Enabling Intervention in Change Management (EICM), developed by Barcellini (2015). "Enabling" is used with the meaning proposed by Constructive Ergonomics (Falzon, 2014), in reference to Sen's work (Sen, 2003). EICM promotes learning and development dynamics, with the general objective of an ergonomic intervention: to transform work in order to allow individuals and collectives to act effectively, to safeguard their health, and to promote their performance (Arnoud, 2013; Raspaud, 2014; Barcellini, 2015). Barcellini (2015: 94) sees the management of change as "a project of collective conception of the work" and an opportunity to provide support, equipped by participative and constructive methodologies, by (1) defining the intention of transformation, combined with (2) collective decisionmaking in close relation to (3) an understanding of the consequences of these two actions on real and future work. This first EICM proposal is grounded in experience from the industrial and service sectors. We posit that the EICM can be organized and led differently in a work environment that is far less structured for the worker, and that is constantly changing, largely unpredictable, and sometimes controversial; the question is: How much can the agricultural sector be representative of such a working environment? (Duru et al., 2014; Prost et al., 2017).

We propose to support farmers in the design of their new work system geared towards agroecology, by the implementation of an EICM. This paper discusses our proposition to build the first step of the EICM, called the chronicle of change (Chizallet et al., 2016). The understanding of the change process toward more agroecological practices, from a work point of view, could help us to support farmers' change and "to facilitate [their] reflective process regarding [their] own work so that [they] can define how to improve and to reorganize it if [they] so desire" (Cerf and Sagory, 2004: 626; Coquil, 2014). Supporting a reflective activity means allowing the farmer to build reflection on his/her past actions (e.g. Mollo and Nascimento, 2013), to "self-renew" and to adapt to different situations. It can also be a source of learning and provide a foundation of knowledge necessary for the development of farmers' design activity as part of their change management (Chizallet et al., submitted). Thus, the chronicle of change consists in proposing a "tool time-space" that:

- helps in understanding the past and on-going changes;

- facilitates a multidimensional analysis of changes in farmers' work system;

- encourages farmers' reflective approach to their work and the process of change;

- reinforces the management of change.

Based on ACE, we analyze change as processes of project management (Fig. 1). This framework is also used by Béguin and Pueyo (2011) with regard to sustainable agriculture, and we support their argument. Figure 1 articulates an intention about the future and how, by adjustments, the situation responds to the realization of this intention (Martin, 2004; Béguin and Pueyo, 2011). These elements "can be considered 
Table 1. Interview strategy for building the chronicle of change.

Tableau 1. Stratégie d'entretien pour construire la chronique du changement.

\begin{tabular}{ll}
\hline Type of interview & \multicolumn{1}{c}{ Goals } \\
\hline An exploratory interview (2h) & To have an overview of agricultural work on the farm \\
$\begin{array}{l}\text { A semi-structured workshop: } \\
\text { "Trace change until today" (3h) }\end{array}$ & $\begin{array}{l}\text { To initiate discussion about the changes between the farmers and the } \\
\text { ergonomist, based on a schematic construction of the process of change } \\
\text { To identify farmers' difficulties, goals and resources (Fig. 2) }\end{array}$ \\
$\begin{array}{l}\text { Four tracking interviews (updates of the chronicle } \\
\text { of change, 1h each) }\end{array}$ & $\begin{array}{l}\text { To pursue the goals of the semi-structured workshop over time by carrying on } \\
\text { adding information to the chronicle of change (Fig. 3) }\end{array}$ \\
A synthetic interview (2h) & $\begin{array}{l}\text { To identify the goals and/or difficulties that are no longer perceived as such by } \\
\text { the farmers, or reformulate them according to their evolution } \\
\text { To identify the goals and/or difficulties of most concern to the farmers } \\
\text { To build an "action plan" to achieve a goal and/or overcome a difficulty }\end{array}$ \\
\hline
\end{tabular}

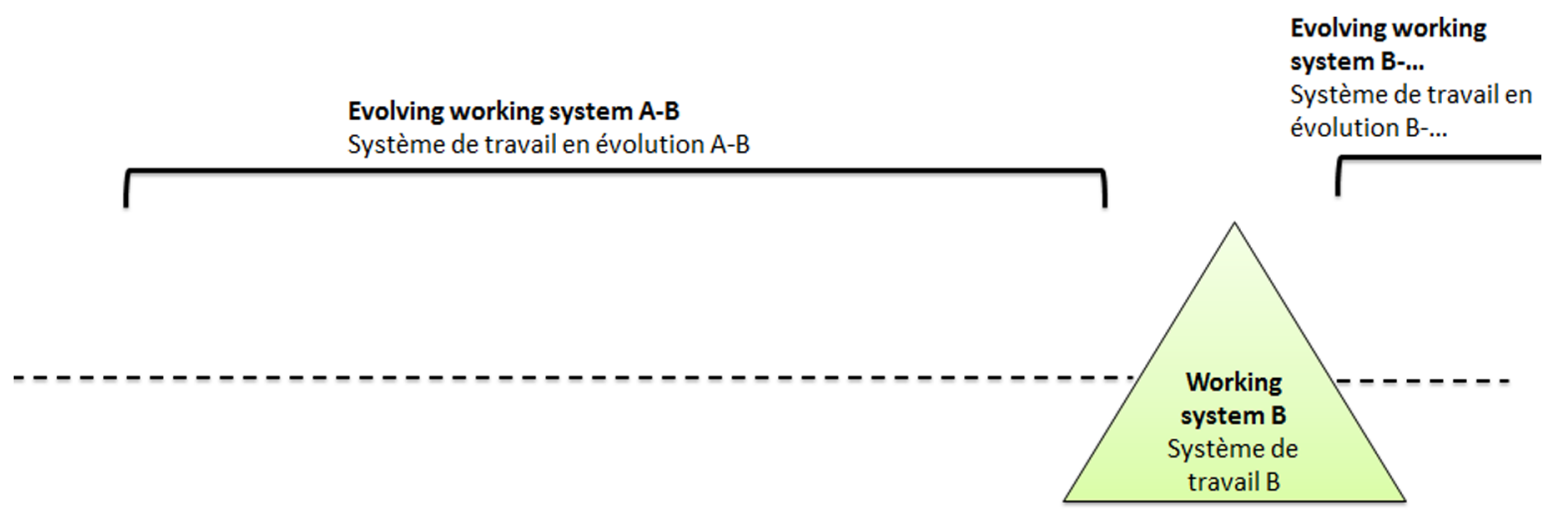

Accompaniment

Accompagnement

Fig. 2. The chronicle of change tool.

Fig. 2. L'outil chronique du changement.

from the angle of multiple dichotomies: definition and problem solving, desirable and possible, opportunity for choices and determinations" (Béguin and Pueyo, 2011: 18).

We assume that the three dimensions of intention, feasibility and adjustment can significantly help farmers to initiate reflection on their change process and their work. Therefore, in the chronicle of change, we will be interested in farmers' intentions, which we will translate in terms of their goals. We will attempt to access the "search for feasibility" by focusing on the difficulties faced by farmers. To understand the adjustments made by farmers between their goals and their difficulties, we will examine the resources that they employ, build, or lack. Furthermore, we will analyze how discussing these difficulties, resources and goals with farmers support them in building a representation of their work system. In this context, our research action combines comprehensive and pragmatic objectives. First, we sought to understand two farmers' work, the agricultural work system in which they functioned, and the process of change. Second, we endeavored to initiate reflection with the farmers about changes in their work, in order to support their management of change. Third, with the farmers, we identified the improvements towards which they wanted to work, as a basis for the design of a future agricultural work system.

\section{Methodological contribution: building a chronicle of change}

\subsection{Presentation of the chronicle of change}

The chronicle of change can be built in four steps (Tab. 1). Through these steps, the farmers built a chronicle of change tool, as shown in Figure 2, with post-it notes corresponding to their difficulties, goals and resources, in the time-frame of the change. During the synthetic interview, they discussed all of the points on the post-it notes: they were asked whether their goals and difficulties had shifted or not, and then prioritized them by selecting those difficulties and goals on which they wanted to work and to evolve first. 


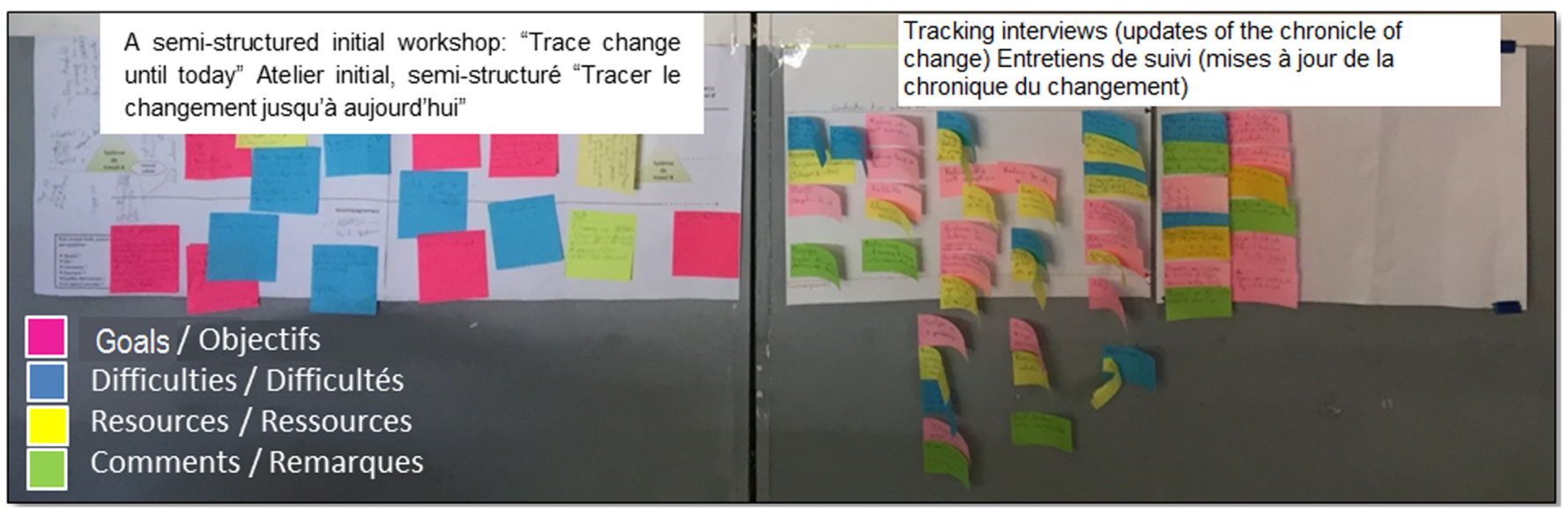

Fig. 3. A chronicle of change completed by two grain farmers, with four tracking interviews (updates of the chronicle of change) over one year. Fig. 3. Une chronique du changement complétée par deux céréaliers, avec quatre entretiens de suivi (mises à jour de la chronique du changement) pendant un an.

Table 2. Categories included in data processing.

Tableau 2. Catégories utilisées pour le traitement des données.

\begin{tabular}{lll}
\hline Category & Definition & Example \\
\hline $\begin{array}{l}\text { Goals } \\
\text { Difficulties }\end{array}$ & $\begin{array}{l}\text { Short-, medium- and long-term intentions of the farmers regarding the farm } \\
\text { Problematic situation faced by the farmers, in which the feasibility of a task is } \\
\text { challenged and requires the resolution of one or more problem(s) }\end{array}$ & $\begin{array}{l}\text { Working on living and naturally fertile soil } \\
\text { The farmer's response(s) proposed or considered as possible and/or necessary to some plots } \\
\text { Resources } \\
\text { address a problem situation (difficulty) or intention (goal) }\end{array}$ \\
\hline
\end{tabular}

\subsection{Case study}

This tool (Fig. 2) has been implemented with two grain farmers, in partnership in a SARL (limited liability agricultural company) located in the Centre of France. These two-grain farmers have been partners for four years and have been converting to organic for one and a half years, for ethical and economic reasons. Previously practicing no-tillage crop production, they have maintained this practice. The combination of organic farming and no-tillage crops corresponds to an agriculture recognized as extremely difficult to implement and to sustain in the agricultural world (Lefevre et al., 2013).

In this case, we held an exploratory interview, built the chronicle of change during a workshop, updated it four times with tracking interviews (Fig. 3), and held a synthetic interview a year after the workshop.

\subsection{Data analysis}

The data in this article were collected mainly using the post-it notes filled in, from the workshop up until the synthesis interview. They were processed as shown in Table 2.

As a first step, we identify the different natures of the farmers' difficulties, goals and resources during their change, in order to better understand the dimensions of their agricultural work system. We then analyze the evolution of the agricultural work system, which affords insight into the place of work in the farmer's concerns.

\section{Results: implementation of the chronicle of change tool}

\subsection{Nature of agricultural work system dimension}

Reading the chronicle of change, which reflects the farmers' goals, difficulties and resources, allows us to identify several dimensions that can characterize the farmer's work system such as:

- Technical dimension: "The grass [...] had grown faster than the crop, $[\ldots]$. We didn't harvest, well, just on one plot $[. .$. we really have to clean up before planting."

- Material dimension: "Currently we lack material resources [...]. We're going to buy an eight-row seeder."

- Learning dimension: "We sorted the invoices, in order to send them all to the accountant, thinking to ourselves, shit if only we were able to do a bit more, we'd pay less!"; "I was doing this before being in partnership [...] I was useless at it". The farmers write on a post-it note: "Get to know the accounting software".

- Economic dimension: "Our goal is also to be profitable [...] you've got to produce a lot [...] if you don't have much to sell, you get nowhere."

- Environmental dimension: "We'll be cropping [...] soybeans, colza soon, to move towards biodiversity."

- Working conditions dimension: "In our objectives we also think about working time, see? Avoiding peaks and smoothing things out a bit that would be cool." 
Table 3. Nature of goals, difficulties and resources.

Tableau 3. Nature des objectifs, difficultés et ressources.

\begin{tabular}{lll}
\hline Goals: & Difficulties & Resources \\
\hline Acquiring new skills & Absence of prescription & Acquiring new equipment \\
Acquiring new equipment & Accompaniment / Support & Knowledge and know-how \\
Enlarging the farm & Isolation from the point of view of agronomic & Recruiting \\
Developing a commercial activity & practices / relation to the network of agricultural & Experimenting \\
Economic & actors & Organization of work \\
Environmental & Lack of material means & Network of agricultural actors \\
Ethical - Values & Meteorological & Techniques \\
Exploratory & Organization of work & \\
Better distribution of the workload & Prescription & \\
Modifying the prescription & Outside pressure (lobbying) & \\
Organization of work & Economic & Techniques \\
Reduction of work time - More efficiency & & \\
Profitability & & \\
Health & & \\
Meaning of the profession & & \\
Techniques & & \\
\hline
\end{tabular}

- Social dimension: "That's a problem [...] the people who advise us, they don't give us good advice, it doesn't correspond to where we want to go [...]. That's what forces us to look elsewhere."

- Ethical dimension: "We didn't feel that this system had anything for us [...] where one ploughs and then sits with soil that's totally dependent on fertilizers."

The farmers created a representation of their work system through the narration and then the written formulation of their difficulties, goals and resources. This showed an agricultural work system covering a wide range of dimensions that the farmers planned to change. Table 3 positions these dimensions in terms of the farmers' goals, difficulties and resources.

Table 3 shows that goals were more varied than were difficulties or resources. In addition, we note that many resources were formulated by the farmers as goals; which reinforces an exploratory dimension. However, this formulation, linked to a small number of the dimensions addressed, reveals that not all resources cited by the farmers were directly accessible to them. The farmers had sometimes to build their own tools, but the economic aspect was a major condition of access to certain resources. The question is then about how the chronicle of change could further the exploration of resources accessible to the farmers, of various dimensions and less dependent on the economic conditions. We also examine the necessity for farmers who are changing to agroecological practices, to benefit from relational actors or institutions that can support them in their search for new resources and the mobilization and construction thereof.

To talk more specifically about the work, we note several dimensions, some of which are directly related to the farmers' working conditions and others less so, as in the following example:

- Farmer 1: "We are integrating [...] soybeans, colza tomorrow, to move towards biodiversity."
- Farmer 2: "If you introduce biodiversity, you solve disease, weed and fertility problems" [...]

- Farmer 1: "We incorporated soybeans in our rotation. This bloody soybean presents us with a problem. We are forced to inoculate it [...] once it's done, it will not keep, it's just in time. [...] You can't do it 10 days before. You can't anticipate."

The example illustrates the desire to work with a living soil, permitted by introducing a new crop. However, this introduction created a new technical difficulty for the farmers - soybean inoculation - and an organizational one - the farmers had to organize themselves differently to inoculate soybeans. This example shows that:

- all the decisions made by the farmers, whether technical or environmental in the example, have a strong direct impact in terms of work;

- the farmers' difficulties, goals and resources are in constant interaction and mutually influence each other.

We now want to understand the dynamics of the farmers' work system in situations of change.

\subsection{Towards a more agroecological farming system: a multidimensional agricultural work system in motion}

\subsubsection{Evolution and dynamics of goals, difficulties and resources revealing a strong concern for work}

We want to clarify whether the goals, difficulties and resources evolved during the series of interviews.

Table 4 shows that the farmers did not reveal their goals, difficulties and resources in each interview. The evolution and dynamics of these goals, difficulties and resources were evident in their work system. They covered a wide range of dimensions, highlighted especially during the workshop, and certainly related to its goal to go back in time in order to be 
Table 4. Evolution of the nature of goals, difficulties and resources through interviews.

Tableau 4. Évolution de la nature des objectifs, difficultés et ressources au cours des entretiens.

\begin{tabular}{|c|c|c|c|c|c|}
\hline & \multirow{2}{*}{$\begin{array}{c}\text { Semi- } \\
\text { structured } \\
\text { workshop } \\
(\mathbf{1 6} / \mathbf{1 2} / 15)\end{array}$} & \multicolumn{4}{|c|}{ Four tracking interviews (updates of the chronicle of change) } \\
\hline & & $\begin{array}{c}1 \\
(09 / 08 / 16)\end{array}$ & $\begin{array}{c}2 \\
(19 / 09 / 16)\end{array}$ & $\begin{array}{c}3 \\
(12 / 10 / 16)\end{array}$ & $\begin{array}{c}4 \\
(02 / 11 / 16)\end{array}$ \\
\hline \multirow{13}{*}{ ڤั๊ } & \multicolumn{5}{|c|}{ Economic } \\
\hline & \multicolumn{5}{|l|}{$\begin{array}{l}\text { Meaning of the } \\
\text { profession }\end{array}$} \\
\hline & \multicolumn{5}{|l|}{ Environmental } \\
\hline & \multicolumn{5}{|l|}{ Health } \\
\hline & \multicolumn{5}{|c|}{ Techniques } \\
\hline & Ethics - Values & & & & \\
\hline & $\begin{array}{l}\text { Organization of } \\
\text { work }\end{array}$ & & & & \\
\hline & Exploratory & & & & \\
\hline & \multicolumn{3}{|c|}{ Less time working - more efficiency } & & $\begin{array}{l}\text { Less time working - } \\
\text { more efficiency }\end{array}$ \\
\hline & \multirow[t]{4}{*}{$\begin{array}{l}\text { Enlarging the } \\
\text { farm }\end{array}$} & & & & \\
\hline & & & & \multicolumn{2}{|c|}{ Acquiring new equipment } \\
\hline & & & & & Acquiring new skills \\
\hline & & & & & $\begin{array}{l}\text { Modifying the } \\
\text { prescription }\end{array}$ \\
\hline \multirow{8}{*}{ 总 } & Economic & & & Economic & \\
\hline & $\begin{array}{c}\text { Outside } \\
\text { pressure } \\
\text { (lobbying) } \\
\end{array}$ & & & & \\
\hline & $\begin{array}{l}\text { Isolation with } \\
\text { regard to } \\
\text { agronomic } \\
\text { practices / } \\
\text { network of } \\
\text { agricultural } \\
\text { actors } \\
\end{array}$ & & & & \\
\hline & $\begin{array}{l}\text { Absence of } \\
\text { prescription }\end{array}$ & & & & $\begin{array}{l}\text { Presence of } \\
\text { prescription }\end{array}$ \\
\hline & \multicolumn{4}{|c|}{ Techniques } & \\
\hline & \multicolumn{5}{|l|}{$\begin{array}{l}\text { Accompaniment } \\
\text { / Support }\end{array}$} \\
\hline & \multicolumn{5}{|l|}{ Meteorological } \\
\hline & & & & & $\begin{array}{c}\text { Lack of material } \\
\text { means }\end{array}$ \\
\hline \multirow{6}{*}{ 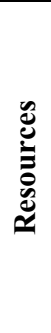 } & \multicolumn{4}{|c|}{ Techniques } & \\
\hline & $\begin{array}{c}\text { Knowledge and } \\
\text { know-how }\end{array}$ & & $\begin{array}{c}\text { Knowledge and } \\
\text { know-how }\end{array}$ & & \\
\hline & $\begin{array}{c}\text { Network of } \\
\text { agricultural } \\
\text { actors }\end{array}$ & & & $\begin{array}{c}\text { Network of } \\
\text { agricultural actors }\end{array}$ & \\
\hline & Experimenting & & & & \\
\hline & & & Recruiting & & \\
\hline & & & & quiring new equipm & \\
\hline
\end{tabular}

comprehensive in this respect. Three dimensions appear as key in this table: the economic dimension, the technical dimension and the theme of work.

The economic dimension was raised as a goal (workshop, tracking interviews 1 and 2) and a difficulty (workshop, tracking interview 3). The goals that appeared after the workshop (to modify the prescription, acquire new equipment, and acquire new competence) were related to the economic aspect: modification of the closing date of the fiscal year and better knowledge of the accounting software that would allow the farmers to anticipate investments in new equipment. The farmers' economic difficulty can be 
Table 5. Evolution of the nature of difficulties and goals until the synthetic interview.

Tableau 5. Évolution de la nature des difficultés et objectifs jusqu'à l'entretien de synthèse.

\begin{tabular}{|c|c|c|c|}
\hline \multicolumn{2}{|c|}{ Difficulties } & \multicolumn{2}{|c|}{ Goals } \\
\hline $\begin{array}{c}\text { Workshop }+ \text { Four } \\
\text { tracking interviews } \\
\text { (updates of the chronicle of } \\
\text { change) }\end{array}$ & Synthesis & $\begin{array}{c}\text { Workshop }+ \text { Four } \\
\text { tracking interviews } \\
\text { (updates of the chronicle of } \\
\text { change) }\end{array}$ & Synthesis \\
\hline \multicolumn{2}{|c|}{ Economic } & \multicolumn{2}{|c|}{ Economic } \\
\hline Outside pressure (lobbying) & & $\begin{array}{l}\text { Meaning of the } \\
\text { profession }\end{array}$ & \\
\hline \multicolumn{2}{|c|}{$\begin{array}{c}\text { Isolation regarding agronomic practices / relation to the } \\
\text { network of agricultural actors }\end{array}$} & \multicolumn{2}{|c|}{ Environmental } \\
\hline Accompaniment / Support & & Modify the prescription & \\
\hline Absence of prescription & & \multicolumn{2}{|c|}{ Techniques } \\
\hline \multicolumn{2}{|c|}{ Techniques } & \multicolumn{2}{|c|}{ Ethics - values } \\
\hline Lack of material means & & \multicolumn{2}{|c|}{ Organization of work } \\
\hline \multirow[t]{2}{*}{ Meteorological } & & \begin{tabular}{l|l} 
Exploratory & \\
\end{tabular} & \\
\hline & Organization of work & \multicolumn{2}{|c|}{$\begin{array}{c}\text { Reduction of working time - Enhanced efficiency - Better } \\
\text { distribution of workload }\end{array}$} \\
\hline & & \begin{tabular}{|l|l|} 
Enlarging the farm & \\
\end{tabular} & \\
\hline & & \begin{tabular}{c|c}
$\begin{array}{c}\text { Acquiring new } \\
\text { equipment }\end{array}$ & \\
\end{tabular} & \\
\hline & & \multicolumn{2}{|c|}{ Acquiring new skills } \\
\hline & & Health & \\
\hline & & & $\begin{array}{l}\text { Developing a commercial } \\
\text { activity }\end{array}$ \\
\hline
\end{tabular}

explained temporarily in terms of financial harm related to other difficulties. For example, a "dirty" harvest of soybeans that resulted in financial loss, due to a technical difficulty in sorting the soybeans.

The technical dimension was present in the goals of all interviews and also in the difficulties and resources, except in tracking interview 4 . We explain this by the fact that the farmers had to integrate new material and agronomic techniques to convert their plots into organic farming, leading to new technical goals (e.g. "re-establishing inter-crops after summer crops", "being autonomous in nitrogen") and new difficulties (e.g. "soybean inoculation") for which they had to adapt, test and progress in the implementation of new techniques. We believe that technical difficulties did not appear in tracking interview 4 (1) because the farmers might feel more comfortable with the new techniques once they had begun to discover and implement them; and (2) because of the nature of the tasks that the farmers performed during tracking interview 4 , in November.

The theme of work was present in all the dimensions of the agricultural work system mentioned by the farmers during the use of the chronicle of change tool. In others words, the farmers referred to the theme of work indirectly, by explaining dimensions of the agricultural work system. For example, the difficulty "lack of material" could be explained by the farmers' willingness to reduce their working time, in order to gain in efficiency. However, they directly emphasized the work dimension, including during discussions on the construction of the chronicle of change. The reduction of their working time and the fact of being able to gain in efficiency were very present in the farmers' goals (workshop, followed by 1, 2, and 4). We consider three reasons for this:

- the farmers saw change as an opportunity to improve their working and living conditions;

- change brought novelties that could prove to be a heavy workload for farmers to manage;

- change in farming practices involved profound changes in the farmers' work, requiring a significant investment in terms of learning.

\subsubsection{Evolution of goals and difficulties until the synthetic interview: a strong concern for work}

After analysing the evolution of the farmers' difficulties, goals and resources during the four tracking interviews (updates of the chronicle of change), we now turn to the synthetic interview. One year and four tracking interviews after the workshop, we went through all the post-it notes with the farmers, in order to complete the chronicle of change and whatever is still current, or to reformulate it if necessary.

Table 5 shows what types of difficulties and goals were no longer seen as such by the farmers.

Concerning difficulties: external pressures (related to lobbying), a lack of ongoing support, a lack of prescription, a lack of material means, and meteorological hazards.

Concerning goals: the desire to find meaning in their profession, modification of the prescription, exploration (visiting other farms), enlargement of the farm, acquiring new equipment and, finally, preserving their health. 
This table allows us to focus mainly on the theme of work. During the synthetic interview, a major difficulty identified by the farmers was related to the organization of work. More specifically, the farmers put a request to the ergonomist: to work on the "better anticipate" aspect of planning resources in order to improve the organization of their work (e.g. to anticipate the maintenance of agricultural equipment). Finally, the synthetic interview revealed that their work was a major concern for the farmers with the need for support. Therefore, following the synthetic interview, and to continue the intervention, the ergonomist helped them to build a new tool to enable them to meet their goals of "reducing working time and limiting peaks in activity". This tool has been integrated into our EICM approach, for the purpose of developing the farmers' reflectivity and going further: developing a projective activity, with the concern that they fully assumed their role as drivers of change and designers of their work.

\section{Discussion and perspective}

In our case study, we have proposed a "space-time tool" to the farmers to understand their agricultural work system and its evolution toward agroecological practices, based on discussions on their goals, difficulties and resources throughout the change process. Several studies of trajectories seek to understand farmers' change from the point of view of technical development, tasks, their relationship with the environment, or the evolution of their production (e.g. Falconnier et al., 2015; Brédart and Stassart, 2017). The role of our trajectory tool is different as its purpose is to put farmers in their position of designer within a design process of their agricultural work system. In other words, the understanding provided by the tool is dedicated to the farmers and not to the ergonomist, and it aims at supporting them in the building of their own design project. Consistently with Cerf and Sagory (2004), we consider farmers to be the managers, executors and designers of their work, and this is supported by our data. The two-grain farmers were constantly exploring new possibilities and making decisions to make their agricultural work system move forward, and in so doing they were designing it. This has also been shown by Coquil et al. (2014) who highlight farmers' creativity. The ergonomist then becomes a facilitator of the design process begun by the farmers and he/she can do so by questioning the iterations between their intentions (what is desirable, their goals) and a search for feasibility (what is possible, their difficulties). In fact, these iterations fit with the understanding of the design processes that Martin (2004) or Béguin and Pueyo (2011) have proposed: the discussion of these difficulties, resources and goals, supports the building of a representation of farmers' work system and its design. We believe that such a facilitation may be re-appropriated by farm advisors.

Additionally, the farmers of our case study were considering the transition to more agroecological practices as an opportunity to improve their working and living conditions. However, meeting the goals of better working and living conditions required them to draw on new resources or even to create new ones. In our case study, we therefore question the ability of the farmers to achieve certain goals and to overcome certain difficulties, particularly those related to the organization of their work, which is a major difficulty for farmers. This also ties in with Delecourt's work (Delecourt, 2018), which seeks to evaluate farmers' work organization and then design simulation tools for this purpose. In our case study, there were many opportunities for the farmers to draw on or build new resources to improve their working and living conditions, and it seems that these opportunities were highly dependent on the farmers' economic situation. In this sense, we confirm the need to support farmers in their quest for, and their construction and use of, new resources to improve their working and living conditions. To improve the chronicle of change, we need to think about how this tool could further promote the exploitation of more diverse and economically accessible resources for farmers. For that we could refer to Gasselin et al. (2013). Through their "trajectory" tool, they create a cognitive map representing the resources of the project leader on the farm, and the impediments encountered. They believe that resource analysis can strengthen an individual's confidence in the feasibility of their project, and help them to identify areas where there are no resources. We could then consider this approach to explore more resources. To go even further, we could agree with Coquil (2014) who uses the instrumental approach (Rabardel and Pastré, 2005) to discuss how farmers are transferring their available resources into instruments used in their design activity.

We believe that the chronicle of change allows farmers to develop a systemic approach to their work and thus to be reflective. More precisely, the chronicle of change allows them to express their goals, difficulties and resources on their own and to make the change visible on a timeline. In so doing, this tool illustrates the tension between the impulse of a future will and its realization, which is necessary to achieve a project of change (Béguin and Pueyo, 2011). Moreover, it allows one to create "dialogue with the situation" (Schön, 1983), which suggests that it is an interesting framework to bring out reflective activity among farmers. Note that our approach is close to the Change Laboratory and Competence Laboratory methods developed by Engestrom (2014) and his team to stimulate "development" in the activity system, or the use of self-confrontation in the practice of the activity. In this sense, and to promote learning during the intervention, EICM relies on a classic way of analyzing what already exists, and highlighting the difficulties that the operators are facing.

Moreover, to continue the development and modeling of EICM, we posit that it is necessary to link the reflective activity to a projective activity in order to reflect on and design a work system. According to Zara-Meylan, "the past contains all the data for the future", and we agree with her that an assessment of past work situations can be used to predict future work situations. "The events that have occurred in the past months or years constitute a road that has been followed and whose path may turn into a risk for the future" (Zara-Meylan, 2016: 8). We are currently working on this with the two-grain farmers who built their chronicle of change with monthly tracking interviews (updates of the chronicle of change). The farmers are designing a new tool to plan their tasks in relation to their actual work, in order to anticipate their future work. This new tool should solve their difficulty in organizing their work. As follow-up to this article, with the prospect of developing the 
projective activity of farmers, it seems to us necessary to explore the notion of temporality and to investigate the relationship between reflective activity and projective activity (Chizallet et al., submitted).

Finally, we have presented here only one case of the chronicle of change but the tool has been tested with other farmers involved in a process of change toward more agroecological practices, with other characteristics (e.g. farmers voluntarily build their own unstructured change step by step; or change is imposed on some farmers, usually for environmental policy reasons). In addition, we are currently inquiring into the deployment of the chronicle of change and the transition from this approach of ergonomic intervention to non-ergonomic workers such as agricultural advisors. To this end, we collaborate with agricultural advisors at the Centres d'initiatives that promote agriculture and rural areas (the CIVAM), who test the chronicle of change with other farmers. This also allows a continuation in the design of the chronicle change tool.

\section{References}

Arnoud J. 2013. Conception organisationnelle : pour des interventions capacitantes. Doctoral dissertation. Paris, France: Conservatoire national des arts et métiers. https://tel.archives-ouvertes.fr/tel00962450/.

Barcellini F. 2015. Développer des interventions capacitantes en conduite du changement. Comprendre le travail collectif de conception, agir sur la conception collective du travail. France: HDR, Université de Bordeaux. https://tel.archives-ouvertes.fr/tel01150586.

Béguin P, Pueyo V. 2011. Quelle place au travail des agriculteurs dans la fabrication d'une agriculture durable? Perspectives interdisciplinaires sur le travail et la santé (13-1). DOI: 10.4000/pistes. 1708.

Brédart D, Stassart PM. 2017. When farmers learn through dialog with their practices: a proposal for a theory of action for agricultural trajectories. Journal of Rural Studies 53: 1-13.

Carayon P, Smith MJ. 2000. Work organization and ergonomics. Applied ergonomics 31(6): 649-662.

Cerf M, Sagory P. 2004. Agriculture et développement agricole. In : Falzon P, ed. Ergonomie. Paris(France) : Presses Universitaires de France, pp. 621-632.

Chantre E. 2011. Apprentissages des agriculteurs vers la réduction d'intrants en grandes cultures: Cas de la Champagne berrichonne dans les années 1985-2010. Doctoral dissertation, France: AgroParisTech, https://tel.archives-ouvertes.fr/tel-00675226.

Chizallet et al. (submitted). Conduire une transition agroécologique de manière autonome et durable: re-penser le travail passé pour concevoir le travail futur. Psychologie française.

Chizallet M, Barcellini F, Prost L, Cerf M. 2016. Entrer dans l'intervention capacitante en conduite du changement par la construction d'une chronique du changement. Actes du $51^{\mathrm{e}}$ Congrès de la SELF, Marseille, 21-23/09/ 16.

Coquil X. 2014. Transition des systèmes de polyculture élevage laitiers vers l'autonomie. Une approche par le développement des mondes professionnels. Doctoral dissertation, France: AgroParisTech.

Coquil X, Béguin P, Dedieu B. 2014. Transition to self-sufficient mixed crop-dairy farming systems. Renewable Agriculture and Food Systems 29(3): 195-205. DOI: 10.1017/ S1742170513000458.
Daniellou F. 2007. Des fonctions de la simulation des situations de travail en ergonomie. Activités 4(4-2): 77-83.

Daniellou F, Rabardel P. 2005. Activity-oriented approaches to ergonomics: some traditions and communities. Theoretical issues in Ergonomics science 6(5): 353-357.

Delecourt E. 2018. Prise en compte du travail dans les changements de pratiques: outils et informations pour l'accompagnement des agriculteurs. Doctoral dissertation. France: AgroParisTech.

Duru M, Therond O et al. 2014. Un cadre conceptuel pour penser maintenant (et organiser demain) la transition agroécologique de l'agriculture dans les territoires. Cahiers Agricultures 23(2): 84-95.

Engestrom Y. 2014. Learning by expanding: an activity theoretical approach to developmental research, 2nd ed. Cambridge: Cambridge University Press, $338 \mathrm{p}$.

Falconnier GN, Descheemaeker K, Van Mourik TA, Giller KE. 2015. Innovative participatory farming system design: combining onfarm crop/livestock trials with ex-ante trade-off analysis. In: Proceedings of the 5th International Symposium for Farming Systems Design, Montpellier (France), pp. 485-486.

Falzon P. 2014. Constructive ergonomics. USA: CRC Press, 294 p.

Gasselin P, Tallon H, Dalmais M, Fiorelli C. 2013. Trois outils pour l'accompagnement à la création et au développement d'activités : Trajectoire, Cartapp et Edappa. Application à l'installation en agriculture. Montpellier, France: CIRAD, INRA, Montpellier SupAgro, ADEAR LR, Office régional de la culture du LanguedocRoussillon, AIRDIE, 152 p. https://hal.archives-ouvertes.fr/hal00939512/.

Hill SB, MacRae RJ. 1996. Conceptual framework for the transition from conventional to sustainable agriculture. Journal of Sustainable Agriculture 7(1): 81-87.

Hollnagel E. 2009. The ETTO principle: efficiency-thoroughness trade-off: why things that go right sometimes go wrong. UK: Ashgate Publishing Ltd, $150 \mathrm{p}$.

Lefevre V, Capitaine M, Peigné J, Roger-Estrade J. 2013. Conception et évaluation ex-ante de systèmes de culture innovants pour améliorer le fonctionnement des sols en agriculture biologique. In: DinABio 2013, Colloque National sur les Recherches en Agriculture Biologique, Feb 2013, Tours (France), 32, pp. 47-60. https://hal.archives-ouvertes.fr/hal-01173339/.

Martin C. 2004. L'ergonome dans les projets architecturaux. In: Falzon P, ed. Ergonomie. Paris, France: Presses Universitaires de France, pp. 421-435.

Meynard JM, Dedieu B, Bos B. 2012. Re-design and co-design of farming systems. An overview of methods and practices. In: Darnhofer I, Gibbon D, Dedieu B, eds. Farming Systems Research into the 21st Century: The New Dynamic. Dordrecht, Netherlands: Springer, pp. 405-429.

Mollo V, Nascimento A. 2013. Pratiques réflexives et développement des individus, des collectifs et des organisations. In: Falzon P, ed. Ergonomie constructive. USA: CRC Press, pp. 207-221.

Prost L, Berthet ET, Cerf M, Jeuffroy MH, Labatut J, Meynard JM. 2017. Innovative design for agriculture in the move towards sustainability: scientific challenges. Research in Engineering Design 28(1): 119-129.

Rabardel P, Pastré P. 2005. Modèles du sujet pour la conception: dialectiques, activités, développement. Toulouse, France : Octares Editions, 272 p.

Raspaud A. 2014. De la compréhension collective de l'activité réelle à la conception participative de l'organisation: plaidoyer pour une intervention ergonomique capacitante. Doctoral dissertation. France: Conservatoire national des arts et métiers. https://hal. archives-ouvertes.fr/tel-01140901. 
Schön D. 1983. The reflective practitioner: how professionals think in action. USA: Basic Books, 384 p.

Sen A. 2003. Development as capability expansion. In : Fukuda-Parr S, Kumar AS, eds. Readings in human development: concepts, measures and policies for a development paradigm. USA: Oxford University Press, pp. 41-58.
Williams BK. 2011. Adaptive management of natural resourcesframework and issues. Journal of Environmental Management 92(5): 1346-1353.

Zara-Meylan V. 2016. Quelles conceptions temporelles pour analyser l'activité ? Une proposition issue de recherches en ergonomie dans l'horticulture. Activités 13: (13-1). DOI: 10.4000/activites.2732.

Cite this article as: Chizallet M, Barcellini F, Prost L. 2018. Supporting farmers' management of change towards agroecological practices by focusing on their work: a contribution of ergonomics. Cah. Agric. 27: 35005. 